\title{
Pelayanan Konseling Islam pada Remaja yang Tinggal di Lingkungan Pekerja Seks Komersil (PSK) Tanah Abang
}

\author{
Radhiya Bustan \\ Program Studi Psikologi, Fakultas Psikologi dan Pendidikan, \\ Universitas Al Azhar Indonesia, Jl. Sisingamangaraja, Jakarta 12110 \\ Penulis untuk Korespondensi/E-mail: radhiya_bustan@uai.ac.id
}

\begin{abstract}
Abstrak - Pengabdian masyarakat ini berupa pelayanan konseling Islam yang diberikan kepada 20 orang remaja yang tinggal di lingkungan Pekerja Seks Komersial (PSK) Tanah Abang Jakarta Pusat. Tujuannya adalah agar dapat membantu remaja tersebut memecahkan masalah-masalah yang mereka hadapi serta memberikan pemahaman yang lebih mendalam terhadap agama agar segala aktivitas mereka dapat dilandasi sesuai dengan syari'at-syari'at Islam. Hasil dari konseling Islami ini dapat membantu menyelesaikan permasalahan yang mereka hadapi baik dalam lingkungan tempat tinggal, keluarga, sekolah, maupun permasalahan dengan teman. Sebagian besar dari mereka sudah dapat membentuk perilaku baru yang lebih baik dan sesuai dengan nilai Islam.
\end{abstract}

Abstract - Public service in the form of Islamic counseling given to 20 adolescents who live in the neighborhood commercial sex workers in Tanah Abang, Central Jakarta. The goal is to help teenagers solve the problems they face and provide a deeper understanding of the religion, so that they all activities can be based on shariaIslamic law. The result of this Islamic counseling can help resolve the problems they face both in the neighborhood, family, school, and problems with friends. Most of them are able to form a better behavior and in accordance with Islamic values.

Keywords - Islamic counseling, individual counseling, group counseling

\section{PENDAHULUAN}

$\mathrm{M}$ anusia tidak pernah lepas dari masalah dalam kehidupannya, diantaranya adalah permasalahan ekonomi. Terkadang alasan ini membuat seseorang dapat melakukan segala cara untuk memenuhi kebutuhan hidupnya. Tingkat spiritualitas seseorang sangat mempengaruhi sikap dalam mengatasi permasalahan hidup yang dihadapinya. Bagi mereka yang pengetahuan dan pemahaman nilai-nilai agamanya kurang, dapat membuat mereka terjerumus dalam pekerjaan yang tidak sesuai dengan norma agama, sosial, budaya, maupun aturan yang berlaku. Salah satunya adalah menjadi wanita yang bekerja sebagai Pekerja Seks Komersial (PSK), dimana mereka menghasilkan uang dari melakukan hubungan seksual. Fenomena ini muncul salah satunya di daerah Tanah Abang Jakarta Pusat, dimana kehidupan malam Pekerja Seks Komersial (PSK) telah berlangsung sekian lama dan kebanyakan telah menjadi pekerjaan yg turun temurun dalam keluarga mereka. Hal ini tentunya berdampak pada kehidupan keluarga dan lingkungannya, termasuk anak-anak remaja mereka yang sedang mengalami masa pencarian identitas (identity confusion). Menurut Erikson dalam Hurlock (1980) berpendapat bahwa masa remaja merupakan masa mencari identitas. Identitas diri yang dicari remaja berupa usaha untuk menjelaskan siapa dirinya, apa perannya dalam masyarakat [1]. Dalam masa ini, tentunya lingkungan sangat berpengaruh dalam pembentukan identitas mereka. Hal ini merupakan permasalahan yang harus menjadi perhatian bersama. Remaja yang tumbuh di lingkungan PSK seperti ini membutuhkan perhatian untuk dapat mengarahkan mereka kepada konsep identitas diri yang ideal menuju sumber daya manusia yang berguna bagi agama dan bangsanya.

Sebagai makhluk sosial, manusia hidup di dunia tidak terlepas dari pertolongan orang lain dan saling membutuhkan satu sama lainnya karena manusia adalah makhluk sosial. Demikian juga dalam menyelesaikan masalahnya, manusia 
terkadang juga membutuhkan orang lain di lingkungannya untuk membantu mencari jalan keluar dari permasalahannya tersebut. Bercerita kepada orang terdekat biasanya dapat membantu mengurangi beban perasaan. Akan tetapi, banyak juga yang tidak mau menceritakan permasalahannya kepada keluarga atau orang terdekatnya, dengan berbagai alasan diantaranya takut akan membebani perasaan mereka, menjadi subjektif, dan terlibat terlalu jauh, serta alasan lainnya. Untuk itu, biasanya mereka akan mencari bantuan dengan datang kepada psikolog atau konselor profesional untuk melakukan proses konseling.

Definisi konseling profesional yang diterima oleh American Counseling Association (ACA) adalah aplikasi dari prinsip-prinsip kesehatan mental, psikologi, atau perkembangan manusia melalui intervensi kognitif, afektif, behavioral atau sistematik, strategi yang memperhatikan kesejahteraan (wellness), pertumbuhan pribadi, atau pengembangan karier, tetapi juga patologi [2].

Konseling merupakan pelayanan dalam membantu menyediakan kondisi untuk individu agar dapat memenuhi kebutuhan untuk hidup berarti, mempunyai rasa aman, kebutuhan untuk cinta dan respek, harga diri, dapat membuat keputusan serta aktualisasi diri. Seorang konselor akan memberikan kesediaan untuk mendengarkan riwayat hidup kliennya, apa yang menjadi harapanharapannya, kegagalan-kegagalan yang dialami, emosi-emosi dan tragedi dalam hidupnya, dan masalah-masalah yang dihadapinya.

Untuk membantu mengatasi permasalahan yang terjadi terutama permasalahan yang dihadapi oleh remaja yang tinggal di lingkungan kehidupan Pekerja Seks Komersil (PSK) di Tanah Abang, maka peran sosial seorang konselor terasa sangat dibutuhkan. Perlu adanya pelayanan konseling islami yang melibatkan keseluruhan sistem keluarga, termasuk orang tua dan saudara-saudara kandung mereka. Konseling keluarga ini diawali dengan konseling individu maupun konseling kelompok untuk mendiagnosis permasalahan remaja tersebut, kemudian konselor akan melakukan konseling islami agar sistem keluarga dapat membantu pertumbuhan positif terhadap klien. Selain itu, direncanakan akan diadakan training motivasi dan pelatihan keterampilan guna meningkatkan taraf hidup mereka, diharapkan mereka mempunyai alternatif pekerjaan yang positif, tidak menjadi pengangguran, dan terjerumus untuk ikut menjadi Pekerja Seks Komersial (PSK) sebagaimana yang kerap mereka lihat di lingkungan mereka.

Harapan terhadap kegiatan ini adalah agar dapat memberikan wawasan, perbaikan untuk meningkatkan kehidupan individu menjadi lebih baik, serta tanggung jawab setiap individu pada kehidupan sekarang ini agar mandiri, sejahtera, bahagia dan sesuai dengan petunjuk Allah dalam menjalaninya. Untuk itu, fokus pelayanan pengabdian masyarakat berupa konseling islami ini adalah remaja yang tingal di lingkungan Pekerja Seks Komersial (PSK) Tanah Abang Jakarta Pusat beserta keluarganya.

\section{Permasalahan}

Berdasarkan hasil penelitian pendahuluan (preliminary research), sumber-sumber masalah yang mereka hadapi adalah sebagai berikut:

1. Masa remaja adalah masa pencarian identitas diri, namun sangat disayangkan beberapa orang anak sudah diproyeksikan oleh orangtuanya untuk menjadi Pekerja Seks Komersil (PSK). Karena kebiasaan yang berlaku di daerah tersebut, anak yang memiliki orangtua yang berprofesi sebagai Pekerja Seks Komersil (PSK) akan meneruskan profesi orangtuanya di saat mereka sudah dewasa nanti.

2. Adanya kondisi alienasi, stress dan depresi mental akibat tekanan di lingkungan tempat tinggal maupun keluarga, serta konflik individu.

3. Minimnya pemahaman mereka tentang konsep keberagamaan, sehingga mereka membutuhkan bekal yang cukup dari segi agama yang mampu membentengi mereka dari perilaku yang tidak sesuai dengan norma agama, sosial, budaya, serta aturan yang berlaku.

4. Remaja tersebut tinggal di lingkungan para Pekerja Seks Komersil (PSK), yang akan memberikan pengaruh terhadap pembentukan kepribadian dan identitas diri mereka.

5. Tidak memiliki jaminan sosial yang layak, seperti : penghasilan per-bulan keluarga di bawah Upah Minimum Regional (UMR) untuk DKI Jakarta UMP 2013 sebesar Rp2.200.000 (http://id.wikipedia.org/wiki/Penetapan_Upah_ Minimum_tahun_2013) [3].

6. Tinggal di rumah dengan kondisi yang tidak layak.

Berdasarkan sumber-sumber masalah tersebut, maka kami memilih remaja-remaja yang tinggal di lingkungan PSK Tanah Abang ini sebagai subyek kegiatan pengabdian masyarakat. Adapun fokus 
permasalahan yang akan dijawab melalui kegiatan pengabdian masyarakat ini adalah:

1. Apakah metode konseling Islami dapat membantu menyelesaikan masalah-masalah serta memberikan penguatan psikologis pada remaja yang tinggal di lingkungan PSK Tanah Abang Jakarta Pusat, terutama yang menjadi santri di Pengajian Hurin'in?

2. Apakah kegiatan pengabdian masyarakat yang dilakukan dapat memberikan pemahaman yang lebih mendalam terhadap agama bagi remaja tersebut?

\section{Tujuan}

Pelayanan konseling islami pada remaja yang tinggal di lingkungan Pekerja Seks Komersial (PSK) di daerah Tanah Abang Jakarta Pusat ini secara umum bertujuan untuk:

1. Membantu remaja tersebut dapat memecahkan masalah-masalah yang mereka hadapi

2. Memberikan pemahaman yang lebih mendalam terhadap agama agar segala aktivitasnya dapat dilandasi sesuai dengan syari'at Islam.

3. Memberikan penguatan psikologis kepada remaja dengan adanya dukungan dari keluarga untuk membuat perubahan positif pada perkembangan masa depan remaja tersebut.

\section{Manfaat}

Pelayanan konseling individu yang diberikan diharapkan dapat memberikan manfaat sebagai berikut:

1. Bagi khalayak. Manfaat konseling individu ini secara khusus adalah agar dapat membantu menyelesaikan permasalahan dalam kehidupan peserta konseling dan mengajak individu tersebut agar dapat menuju jalan yang sesuai dengan petunjuk Al Qur'an dan Hadits. Secara umum, diharapkan konseling ini dapat membantu terbentuknya sumber daya manusia yang lebih berkualitas, dapat memahami tugas dan tanggungjawab sebagai khalifah di muka bumi ini; mampu memelihara dan menjaga dirinya dari perbuatan-perbuatan dosa; serta dapat mengembangkan kreativitas dan dari produktivitas menuju kehidupan yang lebih baik.

2. Bagi Program Studi Healing \& Counseling. Adanya umpan balik setelah dilakukan pelayanan konseling, baik terkait bidang akademik maupun non akademik; sebagai sarana praktek konseling bagi mahasiswa dalam usaha memberikan pelayanan kepada masyarakat dalam bentuk konseling.

\section{KERANGKA TEORI}

\section{Pengertian Konseling Islam}

Kegiatan pengabdian ini menggunakan pendekatan konseling Islami. Konseling merupakan hubungan pribadi yang dilakukan secara tatap muka antara dua orang dalam mana konselor melalui hubungan itu dengan kemampuan-kemampuan khusus yang dimilikinya, menyediakan situasi belajar. Dalam hal ini konseli dibantu untuk memahami diri sendiri, keadaannya sekarang, dan kemungkinan keadaannya masa depan yang dapat ia ciptakan dengan menggunakan potensi yang dimilikinya, demi untuk kesejahteraan pribadi maupun masyarakat.

Konseling secara epistimologi diartikan sebagai pemberian nasihat, pemberian anjuran, dan pembicaraan bertukar pikiran kepada klien agar memahami atau mengerti tentang hal yang sedang dialaminya [4]. Konseling sebagai suatu ilmu yang penerapannya memerlukan suatu keahlian secara profesional, keahlian tersebut di antaranya adalah bagaimana mengadakan percakapan antara klien dengan konselor, dalam percakapan tersebut mempunyai efek yang akan meringankan problem hidup, memecahkan masalah dan melegakan pribadi [5].

Sedangkan konseling Islam adalah suatu aktifitas memberikan bimbingan, pelajaran, dan pedoman kepada individu yang meminta bimbingan (klien) dalam hal bagaimana seharusnya seorang klien dapat mengembangkan potensi akal pikirannya, kejiwaannya, keimanan dan keyakinan serta dapat menanggulangi problem hidup dan kehidupannya dengan baik dan benar secara mandiri yang berparadigma kepada Al-Qur'an dan As-Sunnah Rasulullah SAW [6]. Karena pada dasarnya agama mempunyai makna penting dalam berbagai fungsi kejiwaan, ada yang berfungsi sebagai penyembuhan (kuratif), pencegahan (preventif) dan pembinaan (konstruktif). Sebagaimana Firman Allah SWT dalam Surat Al-Israa' (17) ayat 82:

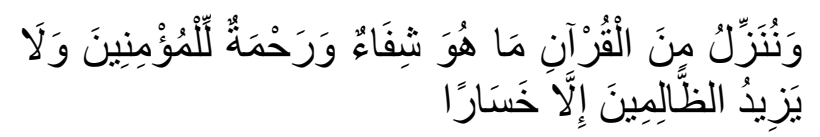

Artinya: "Dan Kami turunkan dari Al Quran suatu yang menjadi penawar/penyembuh dan rahmat bagi orang-orang yang beriman dan Al Quran itu tidaklah menambah kepada orang-orang yang zalim selain kerugian.” (QS. Al-Israa' : 82) 
Pada situasi lain, dalam konseling islami konselor juga dapat mendorong klien untuk melakukan muhasabah, dengan merenungkan hakekat dirinya, mengevaluasi sikap dan perilakunya sekarang yang sudah sesuai dan belum sesuai dengan nilai-nilai Islam. Konselor mendorong agar klien dapat memikirkan yang terbaik untuk kebahagiaan di dunia dan akhirat, tidak semata-mata kesenangan sementara saja[7].

Menurut Erhamwilda (2009), langkah-langkah untuk melaksanakan konseling Islami adalah sebagai berikut [7]:

1. Menciptakan hubungan psikologis yang ramah, hangat, penuh penerimaan, keakraban, keterbukaan.

2. Meyakinkan klien akan terjaganya rahasia dari apapun yang dibicarakan dalam proses konseling sepanjang klien tidak menghendaki diketahui orang lain.

3. Wawancara awal berupa pengumpulan data, sebagai proses mengenal klien, masalahnya, lingkungannya dan sekaligus membantu klien mengenali dan menyadari dirinya.

4. Mengeksplorasi masalah dengan perspektif Islam.

5. Mendorong klien untuk melakukan muhasabah.

6. Mengeksplorasi tujuan hidup dan hakekat hidup menurut klien, selanjutnya merumuskan tujuan-tujuan jangka pendek yang ingin dicapai klien sehubungan dengan masalahnya.

7. Mendorong klien menggunakan hati/qolb dalam melihat masalah dan sekaligus mendorong klien menggunakan 'aqalnya dan bertanya pada hati nuraninya.

8. Mendorong klien untuk menyadari dan menerima kehidupan yang diberikan Allah penuh keridhoan dan keikhlasan.

9. Mendorong klien untuk selalu bersandar dan berdo'a serta mohon dibukakan jalan keluar dari masalahnya kepada Allah SWT, dengan cara memperbanyak ibadah sesuai yang dicontohkan Rasulullah SAW.

10. Mendorong klien untuk mengambil keputusankeputusan strategis yang berisi sikap dan perilaku yang baik (ma'ruf) bagi terselesaikannya masalah yang sedang dihadapi.

11. Mengarahkan klien dalam melaksanakan keputusan-keputusan yang dibuatnya.

12. Mengarahkan dan mendorong klien agar selalu bersikap dan berperilaku yang Islami, sehingga terbentuk sikap dan perilaku yang selalu bercermin pada Al Qur'an dan Hadist.
13. Mendorong klien untuk terus menerus berusaha menjaga diriya dari tunduk pada hawa nafsunya, yang dikendalikan oleh setan yang menyesatkan dan menyengsarakan hidup individu.

\section{Bentuk Pelayanan Konseling}

1. Klasikal/Kelompok

Bentuk-bentuk konseling klasikal/kelompok berupa:

a. Wawancara: proses tanya jawab antar anggota kelompok mengenai topik tertentu. Ini dilakukan di awal konseling kelompok agar anggota kelompok dapat saling mengenal, baik sesama mereka maupun dengan dosen dan mahasiswa/i yang akan memberikan konseling kepada mereka.

b.Diskusi kelompok: dipandu oleh salah seorang mahasiswa sebagai pemimpin kelompok, dan mahasiswa lainnya sebagai observer.

c.Brainstorming: mendiskusikan cara-cara pemecahan satu masalah.

d.Buzz session: diskusi informal tentang topik tertentu yang muncul secara spontan, dipandu pemimpin kelompok.

e. Kelompok aktivitas: aktivitas informal seperti seni dan keterampilan. Anggota kelompok diajarkan untuk dapat menggali kreativitas dan mengasah potensi yang dimiliki.

f. AV activities: aktivitas yang dikembangkan untuk mendiskusikan film, cuplikan film, program $\mathrm{TV}$ atau buku dengan tujuan menstimulasi interaksi dalam kelompok.

g.Bermain peran: 2 klien/lebih menampilkan suatu situasi konflik.

h.Permainan : mengikuti aturan-aturan yang telah ditetapkan.

i. Self-appraisal activities: pengisian inventori,skala konsep diri, penulisan otobiografi, mengumpulkan foto-foto yang dapat membantu individu untuk lebih memahami dirinya, sikap,nilai-nilai dan minatminatnya.

j. Debat: komunikasi antara 2 kelompok yang memiliki pandangan yang bertentangan sehubungan dengan isu tertentu.

k.Diskusi panel: sejumlah anggota kelompok mengumpulkan informasi dan mempersiapkan suatu diskusi tentang topik yang menarik minat seluruh anggota kelompok.

1. Dan lain-lain

2. Individual: Pemecahan masalah secara individu berdasarkan kasus per kasus klien yang diajukan pada konselor. 
3. Keluarga: merupakan perubahan pendekatan dari terapi individual menjadi sebuah conjoint therapeutic relationship, yaitu dimana pasangan melakukan terapi bersama. Konseling keluarga muncul karena kegagalan terapi individual dalam menangani masalah skizophrenia, dan gangguan berat psikologis lainnya. Banyak ahli melihat bahwa lingkungan keluarga sangat berpengaruh besar terhadap perkembangan anggota keluarga yang terganggu, karena keluarga dipandang sebagai sistem kontrak sosial. Terapis harus melihat keluarga sebagai suatu keseluruhan, terutama interaksi diantara para anggotanya

\section{Metode Pelaksanaan Konseling}

Metode-metode yang digunakan dalam pelayanan konseling adalah:

a. Directive; konseling dengan adanya pengarahan. Metode ini dilakukan jika klien benar-benar dalam kondisi kritis dalam memecahkan masalah keluarganya, tingkat pendidikan yang rendah, kepribadian yang tertutup, serta klien kurang memiliki pengetahuan tentang bagaimana konsep keluarga sakinah.

b. Non-directive: konseling dengan tanpa pengarahan. Metode ini dilakukan jika klien dianggap mampu memecahkan masalahnya sendiri. Tiada orang yang lebih tahu masalah dan cara pemecahannya daripada dirinya sendiri. Konselor hanya memberikan stimuli dengan sikap yang empati, penerimaan tanpa syarat, dan menyatu dengan klien agar klien merasa diterima dan merasa mampu memecahkan masalahnya sendiri.

c. Eklektik: kombinasi metode directive dan nondirective.

\section{SOSIALISASI DAN PROFIL RESPONDEN}

\section{Sasaran Khalayak}

Pelayanan konseling ini diberikan pada 20 orang remaja yang tinggal di lingkungan Pekerja Seks Komersial (PSK) di daerah Tanah Abang Jakarta Pusat. Individu yang dimaksud mempunyai kriteria sebagai berikut:

1. Berusia 10 sampai 18 tahun

2. Tinggal di lingkungan Pekerja Seks Komersial (PSK) Tanah Abang, yang sangat tidak produktif dan tidak layak bagi perkembangan kehidupan mereka, baik secara fisik maupun mental spiritual.

\section{Kondisi Subjek Dampingan Saat Ini}

Berdasarkan penelitian pendahuluan mengenai kelompok remaja ini, diperoleh informasi bahwa remaja-remaja ini sudah mengikuti pembelajaran agama Islam di Pengajian HURIN'IN yang berlokasi di jalan jati bunder 7, RT: 17, RW:9, No: 25, Kebon Kacang, Tanah Abang Jakarta Pusat. Pengajian ini dipimpin oleh ustadz Ramli Ishaque. Mereka berjumlah sekitar 20 orang yang berusia 10 sampai 18 tahun. Disamping belajar shalat, puasa, mengaji dengan tajwid, do'a, fikih, dan akhlak, mereka juga memiliki kegiatan ekstrakulikuler seperti belajar musik, marawis dan teater. Remaja-remaja tersebut biasa mengaji mulai pukul 18.00 WIB setiap harinya, sedangkan untuk kegiatan ekstrakulikuler diadakan setiap hari selasa dan sabtu, dibagi ke dalam dua kelompok. kelompok I mulai pukul 15.30 sampai pukul 18.00 sedangkan kelompok II mulai pukul 18.00 sampai 21.00. Berdasarkan informasi yang kami peroleh dari ustadz Ramli, profesi sebagai Pekerja Seks Komersil (PSK) biasanya sudah menjadi profesi turun temurun. Selain itu, kondisi lingkungan sosial yang tidak layak ini juga menimbulkan stress, depresi, dan kondisi alienasi sosial yang terjadi pada mereka. Oleh karena itu remajaremaja tersebut membutuhkan bekal yang baik mengenai pengetahuan agama, pendidikan secara umum dan keterampilan untuk membentengi mereka dari perilaku yang sesat, dan tidak ikut terjerumus dengan profesi sebagai PSK. Perubahan pola pikir ini tentunya juga harus didukung oleh segenap keluarga mereka dan membantu memfasilitasi perubahan yang diharapkan dapat terjadi.

\section{Waktu Dan Tempat}

Kegiatan ini dilakukan mulai Maret sampai bulan Juli 2013 di Pengajian HURIN'IN, jalan jati bunder 7, RT: 17, RW:9, No: 25, Kebon Kacang, Tanah Abang Jakarta Pusat.

\section{Langkah-Langkah Kegiatan Persiapan}

Kegiatan ini dimulai dengan melakukan wawancara kepada pimpinan pengajian HURIN'IN dan para remaja yang tinggal di lingkungan Pekerja Seks Komersil (PSK) di Tanah Abang Jakarta Pusat sebagai studi pendahuluan untuk menganalisa kebutuhan konseling bagi mereka. Persiapan selanjutnya adalah mempersiapkan materi-materi yang berkaitan dengan konseling islami dan pengetahuan agama dalam penciptaan sumber daya manusia yang lebih bermutu dan membantu mereka untuk keluar dari 
permasalahan yang sedang dihadapinya serta menghubungi pihak-pihak yang terkait dengan kegiatan ini, terutama melakukan perkenalan dengan individu-individu serta orang-orang terdekat dari klien seperti orangtuanya yang juga akan diberikan pelayanan konseling.

Selain itu, agar mahasiswa yang terlibat dapat melakukan kegiatan pengabdian masyarakat dengan baik, maka sebagai ketua tim pelaksana saya memberikan pembekalan terlebih dahulu kepada mahasiswa yang berkaitan dengan hal-hal berikut:

1. Penjelasan mengenai kegiatan yang akan dilakukan selama melakukan kegiatan pengabdian masyarakat di pengajian Hurin'in, Tanah Abang, Jakarta Pusat serta penggambaran secara singkat mengenai situasi dan kondisi di pengajian Hurin'in, Tanah Abang, Jakarta Pusat.

2. Pembagian tim pelaksana kegiatan pengabdian masyarakat. Hal ini dilakukan agar terdapat susunan kepanitiaan yang jelas sehingga memudahkan koordinasi dalam melakukan pengabdian masyarakat dan didapatkan hasil yang maksimal.

3. Penyusunan rencana kegiatan Pengabdian Masyarakat di pengajian Hurin'in, sebagai acuan dan panduan hal-hal teknis yang akan dilaksanakan.

4. Merencanakan transport, akomodasi, dan biayabiaya lainnya yang mungkin diperlukan selama melakukan pengabdian masyarakat di pengajian Hurin'in, Tanah Abang, Jakarta Pusat.

\section{Pelaksanaan}

Pelaksanaan pelayanan konseling Islam ini dimulai pada bulan Maret sampai Juli 2013 di Pengajian Hurin'in Tanah Abang, Jakarta Pusat.

\section{Pelaporan}

Langkah terakhir yang dilakukan adalah membuat laporan dari keseluruhan kegiatan pengabdian masyarakat "Pelayanan Konseling Islami Pada Remaja yang Tinggal di Lingkungan Pekerja Seks Komersil (PSK) Tanah Abang - Jakarta Pusat". Disamping itu, akan dilakukan juga evaluasi terhadap kegiatan dengan memberikan kuesioner mengenai tanggapan peserta konseling mengenai pelayanan konseling yang telah diberikan tersebut.

\section{Media}

Media yang digunakan adalah papan tulis, buku tulis sebagai media untuk mencatat kasus setiap klien serta alat-alat tulis lainnya. Selain itu juga dibutuhkan bahan-bahan keterampilan yang digunakan untuk konseling klasikal. Dilengkapi dengan microphone dan media lainnya yang diperlukan saat ceramah dan proses tanya jawab.

\section{Sarana}

1.Tempat Pertemuan, untuk pemberian wawasan tentang bagaimana menerima kenyataan hidup dan bangkit dari permasalahan yang ada, serta mempersiapkan diri menjadi manusia yang lebih beriman dan berkualitas. Serta melakukan kegiatan konseling klasikal seperti keterampilan, dan pelatihan-pelatihan lainnya.

2.Tempat Konseling, untuk konseling individual dan kelompok.

\section{HASIL DAN PEMBAHASAN}

\section{Konseling Individu}

Konseling individu pada kegiatan pengabdian masyarakat ini berupa konseling islami yang dilakukan pada 20 orang remaja pengajian Hurin'in usia 10 sampai 18 tahun. Masing-masing pelaksana kegiatan memberikan pelayanan konseling pada 1 (satu) sampai 2 (dua) orang santri.

Pada praktek konseling individu ini, konselor berusaha mencari tahu mengenai permasalahan yang dihadapi klien (dalam hal ini, remaja pengajian Hurin'in) dan membantu mencarikan alternatif solusi untuk menyelesaikan permasalahan yang dihadapi klien dengan menerapkan teori-teori serta teknik-teknik konseling dengan memasukkan unsur-unsur dan nilai-nilai islam yang berpedoman pada $\mathrm{Al}$ Quran dan Hadist.

\section{Tahap-Tahap Konseling yang Dilakukan}

Praktek konseling individual ini dimulai dengan pembagian klien dengan konselor masing-masing agar setiap sesi klien bertemu dengan konselor yang sama. Tujuannya agar masing-masing konselor dapat melihat dan mengevaluasi sejauh mana konseling yang dilakukan dapat efektif dan memberikan perubahan pada diri klien.

Proses konseling individual diawali dengan building raport yang dilakukan konselor agar dapat membuat klien merasa nyaman untuk mengungkapkan permasalahan yang dihadapi. Tahap ini dimulai dengan perkenalan lebih lanjut antara konselor dan klien. Membuat situasi rileks dan nyaman. 
Tahapan selanjutnya adalah identifikasi \& Penilaian Masalah. Konselor berusaha membahas lebih dalam mengenai masalah-masalah atau kendala yang dihadapi oleh klien dan apa harapan yang diinginkannya dari proses konseling.

Tahapan ketiga dalam proses konseling individual adalah memfasilitasi perubahan klien. Tahapan konseling indivual ini dilakukan dengan cara konselor mencari strategi, alternatif dan intervensi yang dapat memudahkan terjadinya perubahan, seperti membantu klien melihat positif dan negative dari berbagai alternative solusi yang akan dipilih, sehingga klien dapat memilih solusi apa yang paling sesuai untuk dilakukannya. Pada tahap ini, konselor juga memberikan pandangan dari pendekata agama berkaitan dengan masalah yang dihadapi klien. Solusi yang dipilih adalah solusi yang terbaik menurut klien, konselor hanya membantu memberikan pandangan-pandangan yang netral. Pada tahap ini juga dilakukan evaluasi dan kemungkinan konsekuensi dari berbagai alternatif tersebut, dan barulah kemudian klien membuat rencana tindakan dengan komitmen.

Tahapan terakhir dari keseluruhan proses konseling individual adalah evaluasi \& terminasi. Evaluasi dilakukan untuk melihat sampai sejauh mana sasaran konseling tercapai. Keputusan untuk menghentikan konseling karena tujuan sudah tercapai atau klien sendiri yang ingin menghentikannya.

\section{Identifikasi Masalah}

Berdasarkan hasil konseling individu pada 20 orang klien remaja yang tinggal di lingkungan Pekerja Seks Komersial (PSK) Tanah Abang tersebut, dapat disimpulkan bahwa masalah mereka sangat kompleks, diantaranya :

\section{Masalah lingkungan}

Lingkungan yang sangat rentan dengan pergaulan bebas yaitu free sex memaparkan mereka pada situasi-situasi yang mempengaruhi kepribadian mereka. Ada perasaan tidak percaya diri, merasa berbeda dengan teman-teman di sekolah yang tinggal di lingkungan lebih layak. Namun sebagian mereka ada yang menjadi terbiasa dan menganggap pergaulan bebas tersebut adalah tradisi lingkungannya.

\section{Masalah pergaulan di dalam lingkungan sehari- hari}

Pergaulan dengan masyarakat sekitar yang mungkin keras dan bebas, kerap kali terjadi tawuran antar kampung atau daerah hanya untuk menunjukan siapa yang kuat dan mempunyai kekuasaan daerah. Sesuai dengan masa perkembangan remaja, mereka juga banyak yang mengalami masalah dengan pencarian identitas diri. Mereka susah menentukan arah dan tujuan hidup mereka menjadi lebih baik dari agama, pendidikan maupun sosial.

\section{Masalah dalam keluarga}

Yang biasa di ungkapkan oleh klien untuk masalah keluarga adalah masalah ekonomi, klien mempunyai keinginan untuk membeli sesuatu akan tetapi hal itu tak kesampaian dan uang jajan yang kurang memenuhi kebutuhan sehari hari. Sehingga klien harus membantu orangtuanya berdagang setelah pulang sekolah untuk membantu ekonomi keluarga dan menambah uang jajan. Di samping itu pola asuh orangtua yang cenderung otoriter dan menggunakan kekerasan verbal maupun fisik dalam mendidik anak.

\section{Masalah di dalam lingkungan sekolah}

Masalah di lingkungan sekolah umum sekali, mengenai hubungan dengan guru dan teman. Ada guru yang dianggap baik dan ada pula yang di takuti atau keras. Sebagian mereka ada yang suka membolos, tauran, serta mendapatkan nilai yang jelek.

\section{Masalah di dalam pertemanan}

Masalah utama dalam pertemanan adalah memilih teman yag memberikan pengaruh baik sangatlah sulit. Karena lingkungan yang kurang mendukung, sehingga baik dan buruk menjadi abu-abu, kadang ada anak SD pun yang sudah merokok, minuman keras dan lain sebagainya.

\section{Intervensi}

Pendekatan/teori konseling yang digunakan untuk membantu menyelesaikan masalah yang dihadapi klien dalam kegiatan pengabdian masyarakat ini lebih banyak berfokus pada pendekatan islam berlandaskan ajaran Al Qur'an dan Hadits dengan mengajak klien bermuhasabah, untuk merenungi dan memperbaiki diri kedepannya.

Metode konseling yang dilakukan lebih cenderung direktif, yaitu konseling yang berfokus pada konselor dalam memberikan pandangan mengenai masalah klien dan alternatif penyelesaiannya menurut pandangan Islam.

Secara umum, teknik konseling yang digunakan dalam proses konseling adalah sebagai berikut: 
1. Perilaku attending. Dalam konseling yang dilakukan, konselor melakukan attending dengan cara menghampiri klien yang mencakup komponen kontak mata, bahasa tubuh dan bahasa lisan, sehingga membuat suasana menjadi nyaman dan klien dapat mengekspresikan perasaannya dengan bebas.

2. Empati. konselor merasakan apa yang dirasakan klien, merasa dan berpikir bersama klien dan bukan untuk hanyut ke dalamnya. Dalam konseling yang dilakukan, konselor melakukan empati terhadap apa yang dirasakan klien.

3. Refleksi. pemantulan kembali kepada klien tentang perasaan, pikiran dan pengalaman sebagai hasil pengamatan terhadap perilaku verbal dan non verbalnya. Dalam konseling yang dilakukan, konselor melakukan refleksi dengan cara memantulkan kembali atau memberikan feed back terhadap apa yang diungkapkan klien mengenai permasalahannya.

4. Eksplorasi. menggali perasaan, pikiran dan pengalaman klien. Dalam konseling yang dilakukan, konselor melakukan eksplorasi terhadap apa yang diungkapkan klien mengenai permasalahannya.

5. Menangkap pesan (paraphrasing). menyatakan kembali inti ungkapan klien, dengan teliti mendengarkan pesan utama klien, mengungkapkan kalimat yang mudah dan sederhana. Dalam konseling yang dilakukan, konselor melakukan paraphrasing, ketika klien mengungkapkan masalahnya, konselor mengungkapkan kembali dengan cara meringkasnya ke dalam kalimat yang lebih sederhana tetapi tetap mewakili perasaan klien.

6. Pertanyaan terbuka (opened question). Memancing klien agar mau berbicara mengungkapkan perasaan, pengalaman dan pemikirannya. Dalam konseling yang dilakukan, konselor memberikan pertanyaan terbuka untuk memancing klien agar mau terbuka seperti "Apa yang akan kamu lakukan kedepan?"

7. Pertanyaan tertutup (closed question). Pertanyaan yang dijawab dengan kata ya atau tidak atau dengan kata-kata singkat.

8. Dorongan minimal (minimal encouragement). Memberikan dorongan langsung yang singkat terhadap apa yang telah dikemukakan klien, agar klien terus berbicara dan dapat mengarahkan pembicaraan mencapai tujuan.

Dalam konseling yang dilakukan, konselor memberikan dorongan minimal seperti mengucapkan "oh", "ya...ya", "lalu..." kepada klien, pada saat klien menceritakan masalahnya.

9. Interpretasi. mengulas pemikiran, perasaan dan pengalaman klien dengan merujuk pada teoriteori, bukan pandangan subyektif konselor. Dalam konseling yang dilakukan, konselor melakukan interpretasi dengan merujuk pada pendekatan agama berdasarkan rujukan $\mathrm{Al}$ Qur'an dan Hadits serta teori perkembangan Erik Erikson mengenai tugas-tugas perkembangan remaja.

10. Mengarahkan (directing). Mengajak dan mengarahkan klien melakukan sesuatu. Dalam konseling yang dilakukan, konselor mengajak klien untuk bermain dialog dengan tujuan agar klien memperoleh pemahaman mengenai pikiran, perasaan, dan perilakunya.

11. Menyimpulkan sementara (summarizing). Menyimpulkan sementara pembicaraan sehingga arah pembicaraan semakin jelas.

\section{Konseling Kelompok}

Selain konseling individu, dalam pengabdian masyarakat di pengajian Hurin'in, dosen dan mahasiswa Healing \& Counseling juga melakukan konseling kelompok yang melibatkan 25 orang klien. Konseling kelompok dilakukan dengan sharing secara bergantian dan ditutup dengan relaksasi. Tema yang diangkat adalah mengenai perasaan, rasa memiliki mereka terhadap Hurin' in juga membahas tentang penggunaan jejaring sosial (dalam hal ini Facebook), mengenai manfaat dan kerugian dari penggunaannya, dan bagaimana menurut mereka penggunaan yang baik dari Facebook tersebut.

Beberapa remaja Hurin'in mengatakan pendapat dan pikiran mereka tentang Facebook, lalu konselor membantu dengan menggali insight yang diperoleh dari proses diskusi tersebut.

Selain sharing, juga dilakukan relaksasi bersama yang diiringi dengan alunan music instrumental yang lembut, penerangan yang sengaja dipadamkan dan dipandu oleh salah satu mahasiswa Healing \& Counseling (muhasabah).

Relaksasi ini dilakukan untuk menyejukkan hati, menenangkan jiwa dan pikiran serta meningkatkan rasa syukur kepada Allah SWT. Selain itu juga agar meningkatkan iman dan taqwa pada Allah SWT. 


\section{KESIMPULAN DAN SARAN}

\section{Kesimpulan}

Alhamdulillah proses konseling di Majelis Ta'lim dan TPA Hurin'in dapat terlaksanakan dengan baik dan memuaskan. Karena keterlibatan semua unsur, baik pimpinan pengajian, tim pelaksana kegiatan pengabdian masyarakat, serta santriwan/ti yang mau untuk berkomitmen menjalani sesi konseling. Berdasarkan hasil evaluasi dari pihak pengajian Hurin'in yang terdiri dari pimpinan dan guru-guru serta santriwan/ti sebagai klien, maka diperoleh hasil bahwa teknik-teknik konseling islami yang disampaikan kepada mereka sudah mulai dapat diaplikasikan oleh klien. Walaupun tidak seluruhnya, akan tetapi telah menunjukkan adanya perubahan sikap klien untuk lebih memahami tugas dan tanggungjawab sebagai hamba Allah, mampu memelihara dan menjaga dirinya dari perbuatan-perbuatan dosa, serta dapat mengembangkan kreativitas dan produktivitas menuju kehidupan yang lebih baik. Sehingga dapat membantu menyelesaikan permasalahanpermasalahan yang dialami oleh santri-santri Hurin'in.

Selain itu, kegiatan pengabdian masyarakat ini juga disertai dengan diskusi yang melibatkan orangtua santri. Dalam diskusi ini masing-masing orangtua diberi kesempatan untuk mendiskusikan masalah-masalah yang mereka hadapi dalam mendidik anak di rumah. Dosen selaku ketua kegiatan memberikan masukan-masukan terkait tugas perkembangan remaja dan cara mendidik anak berdasarkan pendekatan agama dan psikologi.

Masih banyak masyarakat yang membutuhkan sentuhan lembut dalam berbagai macam permasalahan psikis yang mereka hadapi dalam kehidupan sehari-harinya, baik itu dilingkungan rumah, keluarga, kantor, sekolah dan masih banyak lagi. Untuk itu sangat penting sekali bahwa jurusan Healing \& Counseling yang berwawasan islami ini, sangat tepat dalam membantu menguraikan permasalahan yang menjadi kemelut didalam masyarakat yang pada umumnya kaum muslimin.

\section{Saran}

Saran bagi mahasiswa program studi Healing \& Counseling adalah agar mahasiswa lebih meningkatkan kompetensinya sebagai konselor, baik dari segi pemahaman konsep teori konseling maupun pelaksanaan dalam praktek konseling, agar konseling yang dilakukan dapat lebih tepat sasaran dan bermanfaat tidak hanya bagi klien, namun juga bagi Mahasiswa Healing \& Counseling sendiri, sebagai seorang calon konselor professional nantinya di lapangan pekerjaan.

Saran untuk pihak Universitas Al Azhar Indonesia: 1. Agar terus mendukung kegiatan sejenis guna merealisasikan salah satu poin Tri Dharma Perguruan Tinggi, yaitu Pengabdian Masyarakat.

2. Kegiatan pengabdian masyarakat seperti konseling ini bisa terus dilanjutkan dan dilaksanakan dengan lebih matang, karena sangat dirasakan manfaat serta masukan untuk mahasiswa sangat besar dalam menyelami lebih dalam dan utuh profesi dan kinerja konselor di lapangan.

Berikut beberapa saran bagi pihak Pengajian Hurin'in:

1. Akan sangat baik jika Pengajian Hurin'in memiliki sesi sharing, yang diperuntukkan sebagai wadah komunikasi antara sesama siswa-siswi Hurin'in maupun antara orangtua dengan pengurus Hurin'in. Sesi sharing ini berguna untuk saling berbagi pikiran, saling memberi nasehat dan saling menguatkan agar tidak mudah terpengaruh oleh situasi sosial yang tidak mendukung, seperti lingkungan PSK, NAPZA, pengangguran, dan lain-lain. Bagi orangtua agar mengetahui perkembangan anak-anaknya sehingga dapat memberikan motivasi agar bisa mendidik mereka menjadi generasi muda yang berguna bagi agama dan bangsa.

2. Aktif mengaji di Hurin'in sangat baik bagi siswa-siswi Hurin'in, selain belajar ilmu agama juga dapat belajar kelompok untuk mendiskusikan pelajaran yang di pelajari di sekolah masing-masing. Dengan begitu siswasiswi Hurin'in dapat saling membantu jika mengalami kesulitan dalam memahami pelajaran di sekolah sehingga dapat memperoleh prestasi yang baik di bidang agama maupun pendidikan umum untuk masa depan yang lebih baik. Selain itu, kegitan ini akan mempererat komunikasi yang terjalin antar siswa-siswi Hurin'in satu sama lain. 


\section{DAFTAR PUSTAKA}

[1] Hurlock., Elizabeth B. 1980. Developmental Psychology, A Life Span Approach. McGraw-Hill.

[2] Lesmana, Jeanette Murad. 2005. Dasar-dasar Konseling. Jakarta: UIP.

[3] Http://id.wikipedia.org/wiki/Penetapan_Upah_Mini mum_tahun_2013.

[4] Arifin. 1982. Pedoman Pelaksanaan Bimbingan dan Penyuluhan Agama. Golden Trayon Press. Jakarta.

[5] Surya, Mohamad. 2003. Psikologi Konseling. Pustaka Bani Quraisy: Bandung.

[6] Adz-Dzaky, M. Hamdani Bakran. 2001. Psikoterapi Konseling Islam. Fajar Pustaka Baru. Yogyakarta.

[7] Erhamwilda. 2009. Konseling Islami. Yogyakarta: Graha Ilmu. 